UDK 577.1 : 61

ISSN 1452-8258

\title{
PREOPERATIVE PREALBUMIN-TO-FIBRINOGEN RATIO TO PREDICT SURVIVAL OUTCOMES IN HEPATOCELLULAR CARCINOMA PATIENTS AFTER HEPATIC RESECTION
}

\author{
PREOPERATIVNI ODNOS PREALBUMIN-FIBRINOGEN ZA PREDVIĐANJE PREŽIVLJAVANJA \\ KOD PACIJENATA SA HEPATOCELULARNIM KARCINOMOM NAKON HEPATEKTOMIJE
}

\author{
Haixi Yan ${ }^{1,2}$, Shuaishuai Chen ${ }^{2}$, Yang Qiong ${ }^{2}$, Linling Cai ${ }^{2}$ \\ ${ }^{1}$ Zhejiang Chinese Medical University, Hangzhou 310053, Zhejiang Province, China \\ ${ }^{2}$ Department of Clinical Laboratory, Taizhou Hospital of Zhejiang Province affiliated to Wenzhou \\ Medical University, Linhai 317000, Zhejiang Province, China
}

\section{Summary}

Background: This study aimed to evaluate the clinical application of the preoperative prealbumin-to-fibrinogen ratio (PFR) in the clinical diagnosis of hepatocellular carcinoma (HCC) patients and its prognostic value.

Methods: The clinical and laboratory data of 269 HCC patients undergoing surgical treatment from January 2012 to January 2017 in Taizhou Hospital were retrospectively analysed. The Cox regression model was used to analyse the correlation between the PFR and other clinicopathological factors in overall survival (OS) and disease-free survival (DFS).

Results: Cox regression analysis showed that the PFR (hazard ratio $(H R)=2.123 ; 95 \%$ confidence interval $(95 \% \mathrm{Cl})$, 1.271-3.547; $P=0.004$ ) was an independent risk factor affecting the OS of HCC patients. Furthermore, a nomogram was built based on these risk factors. The $\mathrm{C}$-index for the OS nomogram was 0.715 .

Conclusions: Nomograms based on the PFR can be recommended as the correct and actual model to evaluate the prognosis of patients with HCC.

Keywords: hepatocellular carcinoma, prealbumin-to-fibrinogen ratio, survival analysis, nomogram

Address for correspondence:

Linling Cai

Department of Clinical Laboratory, Taizhou Hospital of Zhejiang Province affiliated to Wenzhou Medical University, 150 Ximen Street of Linhai City, Linhai 317000, Zhejiang Province, China e-mail:cll@enzemed.com

\section{Kratak sadržaj}

Uvod: Cilj ove studije je bio da proceni kliničku primenu preoperativnog odnosa prealbumin-fibrinogena (PFR) $u$ kliničkoj dijagnozi pacijenata sa hepatocelularnim karcinomom (HCC) i njegovu prognostičku vrednost.

Metode: Sprovedena je retrospektivna analiza kliničkih i laboratorijskih podataka 269 pacijenata sa HCC koji su bili na hirurškom lečenju od januara 2012. do januara 2017. u Taizhou bolnici. Za analizu korelacije između PFR-a i drugih kliničko-patoloških faktora u ukupnom preživljavanju (OS) i preživljavanju bez bolesti (DFS) korišćen je Koksov regresioni model.

Rezultati: Koksova regresiona analiza je pokazala da je PFR (indeks rizika $(H R)=2,123 ; 95 \%$ interval pouzdanosti $(95 \% \mathrm{Cl}), 1,271-3,547 ; \mathrm{P}=0,004)$ bio nezavisni faktor rizika koji je uticao na ukupno preživljavanje pacijenata sa HCC. Dodatno, na osnovu ovih faktora rizika je urađen nomogram. C-indeks za nomogram ukupnog preživljavanja je bio 0,715.

Zaključak: Nomogrami zasnovani na PFR-u se mogu preporučiti kao ispravan i stvarni model za procenu prognoze kod pacijenata sa HCC.

Ključne reči: hepatocelularni karcinom, odnos prealbumina i fibrinogena, analiza preživljavanja, nomogram 


\section{Introduction}

Hepatocellular carcinoma (HCC) is a globally prevalent malignant tumour with a 5 -year survival rate $(<5 \%)(1)$. HCC is mainly diagnosed by imaging examinations, serological markers (alpha-fetoprotein, $\alpha$-L-fucosidase, abnormal prothrombin, and so on), and liver histopathological diagnoses. Moreover, China has the highest incidence of liver cancer. According to informal statistics, the number of Chinese people who die of liver cancer each year is approximately 110,000 , accounting for $45 \%$ of the world's liver cancer deaths (2).

Fibrinogen is an important acute-phase protein. Recent studies have found that fibrinogenaemia is strongly related to various tumours' occurrence, development, and prognosis. These tumours mainly include renal cell carcinoma, lung cancer, ovarian cancer, and hepatocellular carcinoma (3-6). Furthermore, prealbumin levels can often be used to assess a patient's nutritional status. Consequently, prealbumin levels can reflect postoperative effects such as cervical cancer, metastatic renal cell carcinoma, and non-small-cell lung cancer (7-9). Furthermore, a new prognostic indicator has been reported, which is a combination of prealbumin and fibrinogen. Several articles have shown that prealbumin and fibrinogen (PFR) ratio has good prognostic significance in acute pancreatitis (10).

Therefore, the trend of early detection and early intervention is crucial for HCC treatment and mortality reduction. Finding new HCC biomarkers to predict the prognosis of HCC patients after surgery is urgent. Thus, this study aimed to use nomograms to analyse the relationship of the preoperative PFR in the prognosis of $\mathrm{HCC}$ patients to determine its prognostic value in $\mathrm{HCC}$.

\section{Materials and Methods}

\section{Patients}

This study recruited $367 \mathrm{HCC}$ patients admitted to the Department of Hepatobiliary Surgery of Taizhou Hospital of Zhejiang Province, Taizhou, China, from January 2012 to January 2017. The inclusion criteria were as follows: (a) complete clinical and laboratory data (current medical history, previous medical history, family history, personal history, physical examination, and complete pathological data); (b) abdominal computed tomography or ultrasound to exclude liver abscess, liver-occupying lesions, and other diseases; (c) the use of required pathological data to exclude secondary liver cancer; (d) postoperative TNM clinical-pathological stages I, II, and III; and (e) exhaustive whole blood cell analysis, biochemical analysis, and examinations. The preoperative clinical diagnosis was clear, and the tumour location, size, number, pathological stage, and differentiation degree were obtained through pathological examination. The intraoperative lymph nodes were examined to determine the lymph node metastasis in each study group. Preoperative blood examination data was exhaustive. Furthermore, the exclusion criteria were (a) patients with other benign liver tumours (e.g., haemangiomas and hepatic adenomas) and (b) patients with infections or other inflammatory diseases. Finally, 269 patients were included.

\section{Treatment and follow-up}

All patients underwent a 1-year regular followup visit. The follow-up deadline was April 22, 2017. The recurrence and survival times were all recorded in months, from surgery to recurrence or death. According to the follow-up data criteria, tumour recurrence or metastasis was the DFS endpoint. Furthermore, the overall survival (OS) endpoint was death.

\section{Statistical analysis}

The Statistical Package for the Social Sciences, version 22.0, and X-tile, version 3.6.1, were used for analysis. The optimal PFR cut-off value was calculated using the $X$-tile plot. The $X^{\prime \prime}$ test was used to analyse the differences between the categorical variables. Moreover, the Cox proportional hazards model was used for univariate and multivariate survival analyses to determine the risk factors for prognosis. Finally, the nomogram for prediction value was established using $\mathrm{R}$ software. Consequently, model accuracy was evaluated by Harrell's concordance index (c-index), calibration plots, decision curves, and clinical impact curves. $P$ values $\leq 0.05$ were considered statistically significant.

\section{Results}

Analysis and calculation of the PFR optimal cutoff value

This study group enrolled 269 patients. Taking postoperative mortality of the patients as the endpoint, 0.8 was the optimal PFR cut-off value calculated by the $\mathrm{X}$-tile plot (Figure 1).

\section{Patient characteristics}

The patients' baseline and clinicopathological characteristics stratified by the PFR are described in Table I. Furthermore, the table shows that the patients were divided into two groups for further analysis (PFR $<0.8$ and PFR 0.8). Moreover, the PFR was associated with the Barcelona Clinic Liver Cancer (BCLC) stage, Child-Pugh score, complications (hepatic rupture, portal hypertension, and intraoperative 
A OS
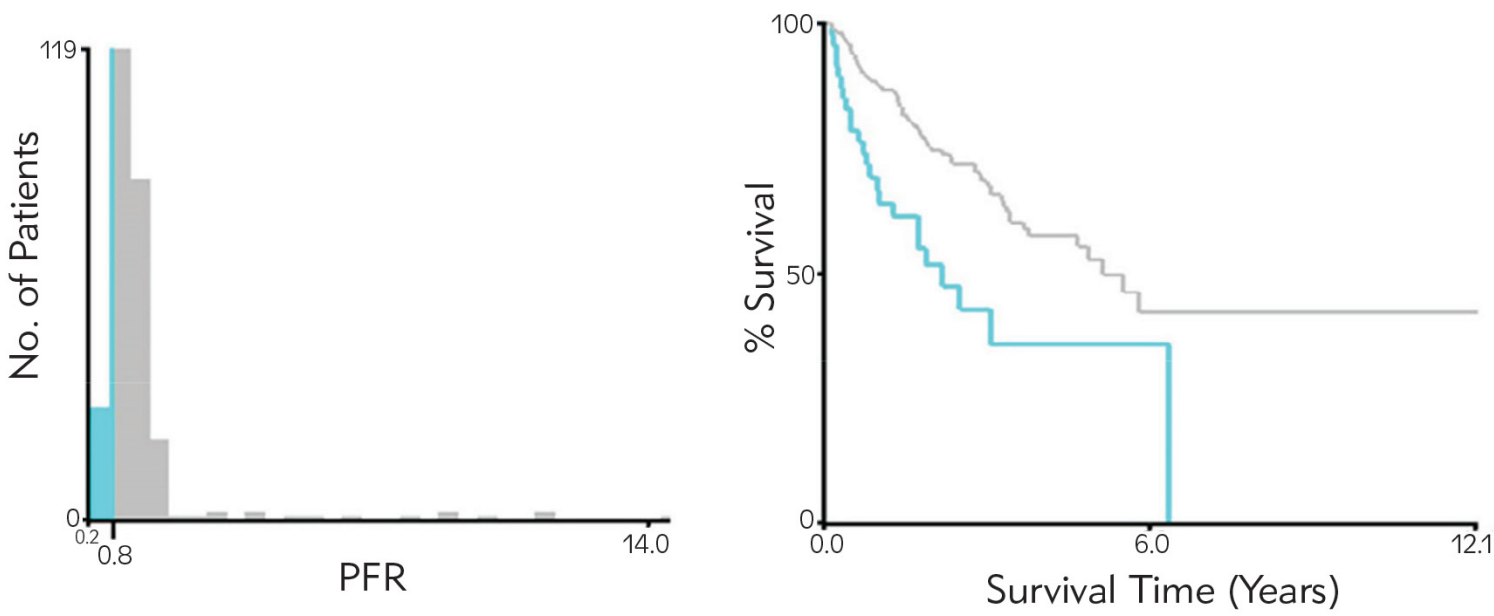

B DFS
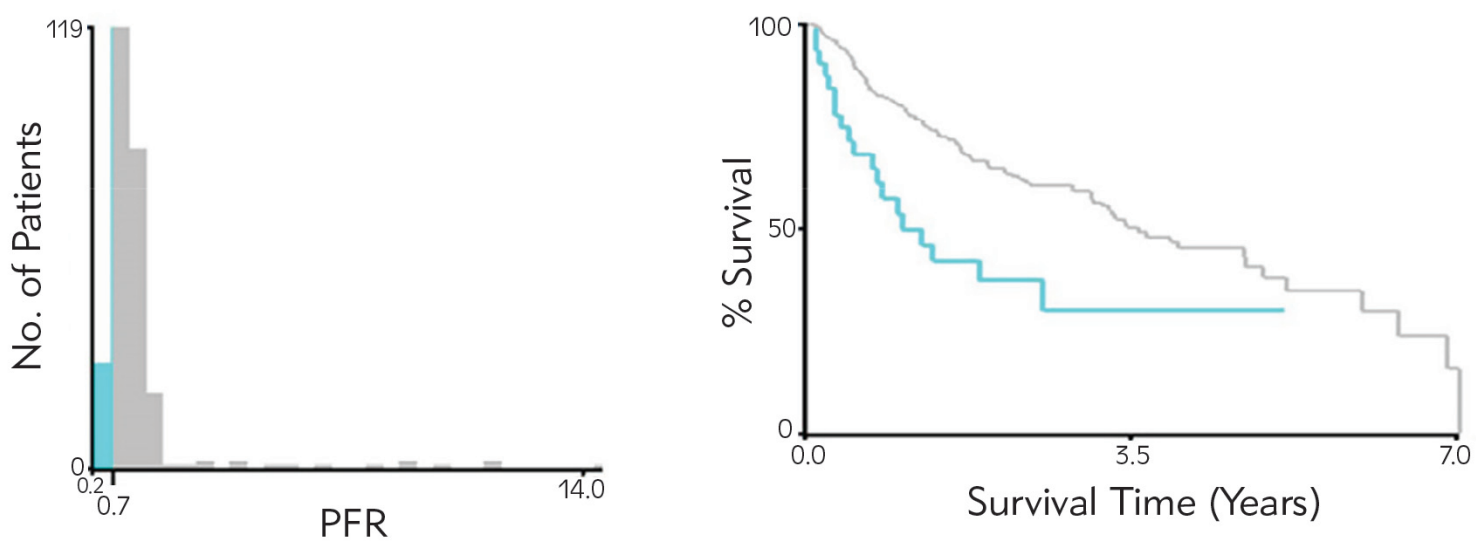

Figure $1 \mathrm{X}$-tile OS analyses were performed using patient data to determine the optimal PFR cut-off values. The optimal cutoff values are shown in the histograms of the entire cohort (left panels), and Kaplan-Meier plots are displayed (right panels). The $P$ values were determined by using the cut-off values defined in the training sets and applying them to the validation sets. A. For OS, the optimal cut-off value of the PFR was 0.8. B. For DFS, the optimal cut-off value of the PFR was 0.7.

ascites), survival, tumour length, and red cell distribution width. The average age of the 269 patients was 57 years, with 219 (81.4\%) males and 50 (18.6\%) females. Moreover, patients with stages A and B-C, using the BCLC staging system, accounted for $55.8 \%$ and $44.2 \%$ of the total patients, respectively. However, patients with grades $A$ and $B$ accounted for $89.6 \%$ and $10.4 \%$ of the total patients' Child-Pugh scores, respectively. Patients with complications of liver rupture bleeding, portal hypertension, and hepatic encephalopathy accounted for $7.8 \%, 6.3 \%$, and $0.7 \%$ of the total patients, respectively. Consequently, 173 patients survived (64.3\%). Of the total patients, 167 (62.1\%) and 102 (37.9\%) were diagnosed with tumours $<5$ and $5 \mathrm{~cm}$, respectively.

\section{Prognostic value of the PFR}

Univariate analysis was carried out using the Cox regression model. Consequently, the clinicopathological parameters predicting OS and DFS were further studied. In the univariate analysis, the BCLC stage, nerve invasion, vascular invasion, $T$ stage, $M$ stage, tumour size, number of tumours and PFR were significantly related to $\mathrm{OS}(p<0.05)$. Furthermore, the BCLC stage, portal hypertension, vascular invasion, $\mathrm{T}$ stage, $M$ stage, tumour size, number of tumours and PFR were associated with DFS $(p<0.05)$. For the multivariate Cox regression OS model, the PFR (hazard ratio $(H R)=2.123 ; 95 \%$ confidence interval $(95 \% \mathrm{Cl}), 1.271-3.547 ; P=0.004)$, vascular invasion $(\mathrm{HR}=2.272 ; 95 \% \mathrm{Cl}, 1.032-5.003 ; P=0.041), M$ stage $(\mathrm{HR}=8.095 ; 95 \% \mathrm{Cl}, 3.518-18.627$; 
Table I Comparison of baseline clinicopathological characteristics based on PFR.

\begin{tabular}{|c|c|c|c|c|c|}
\hline & & Cases & & & $P$ \\
\hline & & No. (\%) & $<0.8$ & $\geq 0.8$ & $r$ \\
\hline Ape (yearc) & $\leq 60$ & 164 (61\%) & 25 & 139 & 0312 \\
\hline Age (years) & $>60$ & 105 (39\%) & 21 & 84 & 0.312 \\
\hline Gondor & Male & $219(81.4 \%)$ & 35 & 184 & 0700 \\
\hline Gender & Female & 50 (18.6\%) & 11 & 39 & 0.508 \\
\hline$C_{0}$ & No & 140 (52\%) & 25 & 115 & 0731 \\
\hline Smoking & Yes & 129 (48\%) & 21 & 108 & 0.150 \\
\hline Drinking & No & $196(72.9 \%)$ & 37 & 159 & 0205 \\
\hline Diniking & Yes & 73 (27.1\%) & 9 & 64 & 0.203 \\
\hline BCIC stane & A & 150 (55.8\%) & 18 & 132 & 0013 \\
\hline DCLC stage & $B, C$ & $119(44.2 \%)$ & 28 & 91 & 0.013 \\
\hline Child Pun croro & $A$ & 241(89.6\%) & 31 & 210 & 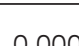 \\
\hline Cnila-rugn score & B & $28(10.4 \%)$ & 15 & 13 & 0.000 \\
\hline Liver rupture & No & $248(92.2 \%)$ & 33 & 215 & 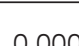 \\
\hline bleeding & Yes & $21(7.8 \%)$ & 13 & 8 & 0.000 \\
\hline Portal hynertension & No & $252(93.7 \%)$ & 37 & 215 & 0000 \\
\hline porlal nypertension & Yes & $17(6.3 \%)$ & 9 & 8 & 0.000 \\
\hline 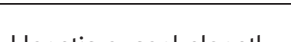 & No & $267(99.3 \%)$ & 45 & 222 & 0215 \\
\hline Hepatic encephalopathy & Yes & $2(0.7 \%)$ & 1 & 1 & 0.213 \\
\hline Recrudescence & No & $146(54.3 \%)$ & 21 & 125 & 0197 \\
\hline Recrudescence & Yes & $123(45.7 \%)$ & 25 & 98 & 0.191 \\
\hline Survival cituntion & Survival & $173(64.3 \%)$ & 23 & 150 & 02026 \\
\hline survival situation & Mortality & 96 (35.7\%) & 23 & 73 & 0.026 \\
\hline Cirrhocic & No & 69 (25.4\%) & 7 & 62 & 0075 \\
\hline Cirmusis & Yes & $200(74.3 \%)$ & 39 & 161 & $0.0 / 5$ \\
\hline Liver capsule & No & 220 (81.8\%) & 37 & 183 & 0795 \\
\hline invasion & Yes & 49 (18.2\%) & 9 & 40 & 0.193 \\
\hline Liver marain & No & 247 (91.8\%) & 39 & 208 & 0056 \\
\hline & Yes & $22(8.2 \%)$ & 7 & 15 & 0.056 \\
\hline Nho . & No & $259(96.3 \%)$ & 45 & 214 & 05072 \\
\hline Nerve invasion & Yes & $10(3.7 \%)$ & 1 & 9 & 0.343 \\
\hline Yaccular invacion & No & $201(74.7 \%)$ & 30 & 171 & 0103 \\
\hline vascular intivasion & Yes & 68 (25.3\%) & 16 & 52 & 0.105 \\
\hline$T$ ctora 100 & T0-T1 & 157 (58.4\%) & 24 & 133 & $0350-20$ \\
\hline I stage & T2-T4 & $112(41.6 \%)$ & 22 & 90 & 0.550 \\
\hline N stage & NO & 264 (98.1\%) & 45 & 219 & $0862-2$ \\
\hline N stage & N1 & 5 (1.9\%) & 1 & 4 & 0.002 \\
\hline 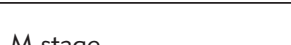 & MO & $263(97.8 \%)$ & 45 & 218 & 0977 \\
\hline M stage & M1 & $6(2.2 \%)$ & 1 & 5 & . \\
\hline Tumour size $(\mathrm{cm})$ & $<5 \mathrm{~cm}$ & $167(62.1 \%)$ & 20 & 147 & 0004 \\
\hline lumour size $(\mathrm{cm})$ & $5 \mathrm{~cm}$ & $102(37.9 \%)$ & 26 & 76 & 0.004 \\
\hline Number of & 1 & 209 (77.7\%) & 38 & 171 & 0370 \\
\hline tumours & 2 & 60 (22.3\%) & 8 & 52 & $0.5 / 9$ \\
\hline Hepatitis B & No & 47 (17.5\%) & 43 & 4 & 097 \\
\hline infection & Yes & $222(82.5 \%)$ & 181 & 41 & 0.091 \\
\hline DIT & $300 \times 10^{9} / \mathrm{L}$ & $259(96.3 \%)$ & 45 & 214 & 05072 \\
\hline PLI & $>300 \times 10^{9} / \mathrm{L}$ & $10(3.7 \%)$ & 1 & 9 & 0.545 \\
\hline$\triangle E P$ & $20 \mu \mathrm{g} / \mathrm{L}$ & $116(43.1 \%)$ & 15 & 101 & 0114 \\
\hline Arr & $>20 \mu \mathrm{g} / \mathrm{L}$ & $153(56.9)$ & 31 & 122 & 0.774 \\
\hline CEA & $\leq 5 \mathrm{ng} / \mathrm{mL}$ & $232(86.2 \%)$ & 41 & 191 & $0533+20+3$ \\
\hline CEA & $>5 \mathrm{ng} / \mathrm{mL}$ & 37 (13.8\%) & 5 & 32 & 0.330 \\
\hline
\end{tabular}


294 Yan et al.:

Table II Univariate and multivariate survival analyses of OS and DFS in HCC patients.

\begin{tabular}{|c|c|c|c|c|c|c|c|c|}
\hline & OS & & & & DFS & & & \\
\hline & $\begin{array}{c}\text { Univariate analysis } \\
\text { HR }(95 \% \mathrm{Cl})\end{array}$ & $P$ & $\begin{array}{c}\text { Multivariate analysis } \\
\text { HR }(95 \% \mathrm{Cl})\end{array}$ & $P$ & $\begin{array}{c}\text { Univariate analysis } \\
\text { HR }(95 \% \mathrm{Cl})\end{array}$ & $P$ & $\begin{array}{c}\text { Multivariate } \\
\text { HR }(95 \% \mathrm{Cl}) \text { analysis }\end{array}$ & $P$ \\
\hline Age (years) & & 0.489 & & 0.389 & & 0.937 & & 0.525 \\
\hline$\leq 60$ & 1.000 & & 1.000 & & 1.000 & & 1.000 & \\
\hline$>60$ & $1.157(0.766-1.749)$ & & 1.010 & & $0.985(0.680-1.427)$ & & $1.133(0.772-1.663)$ & \\
\hline Gender & & 0.948 & & 0.796 & & 0.985 & & 0.991 \\
\hline Male & 1.000 & & 1.000 & & 1.000 & & 1.000 & \\
\hline Female & $0.982(0.574-1.682)$ & & $0.927(0.520-1.651)$ & & $0.995(0.621-1.595)$ & & $0.997(0.614-1.621)$ & \\
\hline Smoking & & 0.545 & & & & 0.424 & & \\
\hline No & 1.000 & & & & 1.000 & & & \\
\hline Yes & $1.132(0.758-1.690)$ & & & & $1.157(0.809-1.653)$ & & & \\
\hline Drinking & & 0.536 & & & & 0.386 & & \\
\hline No & 1.000 & & & & 1.000 & & & \\
\hline Yes & $1.146(0.744-1.766)$ & & & & $1.189(0.804-1.757)$ & & & \\
\hline $\mathrm{BCLC}$ stage & & 0.000 & & 0.421 & & 0.001 & & 0.852 \\
\hline $\mathrm{A}$ & 1.000 & & 1.000 & & 1.000 & & 1.000 & \\
\hline$B, C$ & $2.171(1.445-3.263)$ & & $0.766(0.401-1.466)$ & & $1.800(1.257-2.579)$ & & $0.945(0.523-1.709)$ & \\
\hline Child's score & & 0.055 & & & & 0.123 & & \\
\hline A & 1.000 & & & & 1.000 & & & \\
\hline$B$ & $1.742(0.988-3.073)$ & & & & $1.532(0.891-2.635)$ & & & \\
\hline Liver rupture bleeding & & 0.083 & & & & 0.238 & & \\
\hline No & 1.000 & & & & 1.000 & & & \\
\hline Yes & $1.746(0.930-3.278)$ & & & & $1.433(0.789-2.604)$ & & & \\
\hline Portal hypertension & & 0.068 & & & & 0.002 & & 0.062 \\
\hline No & 1.000 & & & & 1.000 & & 1.000 & \\
\hline Yes & $1.842(0.955-3.551)$ & & & & $2.462(1.378-4.397)$ & & $1.870(0.970-3.604)$ & \\
\hline Hepatic encephalopa- & & 0.547 & & & & 0.727 & & \\
\hline No & 1.000 & & & & 1.000 & & & \\
\hline Yes & $1.833(0.255-13.188)$ & & & & $1.421(0.198-10.193)$ & & & \\
\hline Cirrhosis & & 0.699 & & & & 0.403 & & \\
\hline No & 1.000 & & & & 1.000 & & & \\
\hline Yes & $1.100(0.678-1.787)$ & & & & $1.203(0.780-1.858)$ & & & \\
\hline Liver capsule invasion & & 0.328 & & & & 0.881 & & \\
\hline No & 1.000 & & & & 1.000 & & & \\
\hline Yes & $1.270(0.787-2.048)$ & & & & $1.035(0.661-1.621)$ & & & \\
\hline Liver margin & & 0.085 & & & & 0.234 & & \\
\hline No & 1.000 & & & & 1.000 & & & \\
\hline Yes & $1.782(0.923-3.439)$ & & & & $1.459(0.784-2.717)$ & & & \\
\hline Nerve invasion & & 0.034 & & 0.330 & & 0.168 & & \\
\hline No & 1.000 & & 1.000 & & 1.000 & & & \\
\hline Yes & $2.456(1.071-5.633)$ & & $1.596(0.623-4.086)$ & & $1.787(0.783-4.078)$ & & & \\
\hline Vascular invasion & & 0.000 & & 0.041 & & 0.001 & & 0.151 \\
\hline No & 1.000 & & 1.000 & & 1.000 & & 1.000 & \\
\hline Yes & $2.472(1.619-3.774)$ & & $2.272(1.032-5.003)$ & & $1.938(1.315-2.856)$ & & $1.709(0.823-3.550)$ & \\
\hline T stage & & 0.000 & & 0.938 & & 0.001 & & 0.778 \\
\hline T1 & 1.000 & & 1.000 & & 1.000 & & 1.000 & \\
\hline $\mathrm{T} 2, \mathrm{~T} 3, \mathrm{~T} 4$ & $2.111(1.412-3.157)$ & & $0.966(0.408-2.286)$ & & $1.823(1.276-2.603)$ & & $0.894(0.411-1.947)$ & \\
\hline $\mathrm{N}$ stage & & 0.876 & & & & 0.623 & & \\
\hline No & 1.000 & & & & 1.000 & & & \\
\hline N1 & $1.119(0.272-4.598)$ & & & & $0.698(0.167-2.925)$ & & & \\
\hline M stage & & 0.000 & & 0.000 & & 0.000 & & 0.000 \\
\hline MO & 1.000 & & 1.000 & & 1.000 & & 1.000 & \\
\hline M1 & $13.114(5.515-31.184)$ & & 8.095 (3.518-18.627) & & $8.556(3.679-19.897)$ & & $5.015(2.253-11.163)$ & \\
\hline Tumour length $(\mathrm{cm})$ & & 0.000 & & 0.007 & & 0.001 & & 0.073 \\
\hline$<5 \mathrm{~cm}$ & 1.000 & & 1.000 & & 1.000 & & 1.000 & \\
\hline$\geq 5 \mathrm{~cm}$ & $2.320(1.551-3.471)$ & & $2.188(1.240-3.859)$ & & $1.868(1.306-2.671)$ & & $1.611(0.957-2.711)$ & \\
\hline Number of tumours & & 0.025 & & 0.224 & & 0.004 & & 0.103 \\
\hline 1 & 1.000 & & 1.000 & & 1.000 & & 1.000 & \\
\hline$\geq 2$ & $1.658(1.067-2.577)$ & & $1.532(0.770-3.048)$ & & $1.770(1.197-2.617)$ & & $1.714(0.896-3.278)$ & \\
\hline Hepatitis B infection & & 0.630 & & & & 0.674 & & \\
\hline No & 1.000 & & & & 1.000 & & & \\
\hline Yes & $0.816(0.357-1.867)$ & & & & $0.849(0.395-1.822)$ & & & \\
\hline PFR & & 0.001 & & 0.004 & & 0.007 & & 0.092 \\
\hline$\geq 0.8$ & 1.000 & & 1.000 & & 1.000 & & 1.000 & \\
\hline$<0.8$ & $2.261(1.411-3.624)$ & & $2.123(1.271-3.547)$ & & $1.829(1.175-2.848)$ & & $1.525(0.934-2.491)$ & \\
\hline
\end{tabular}



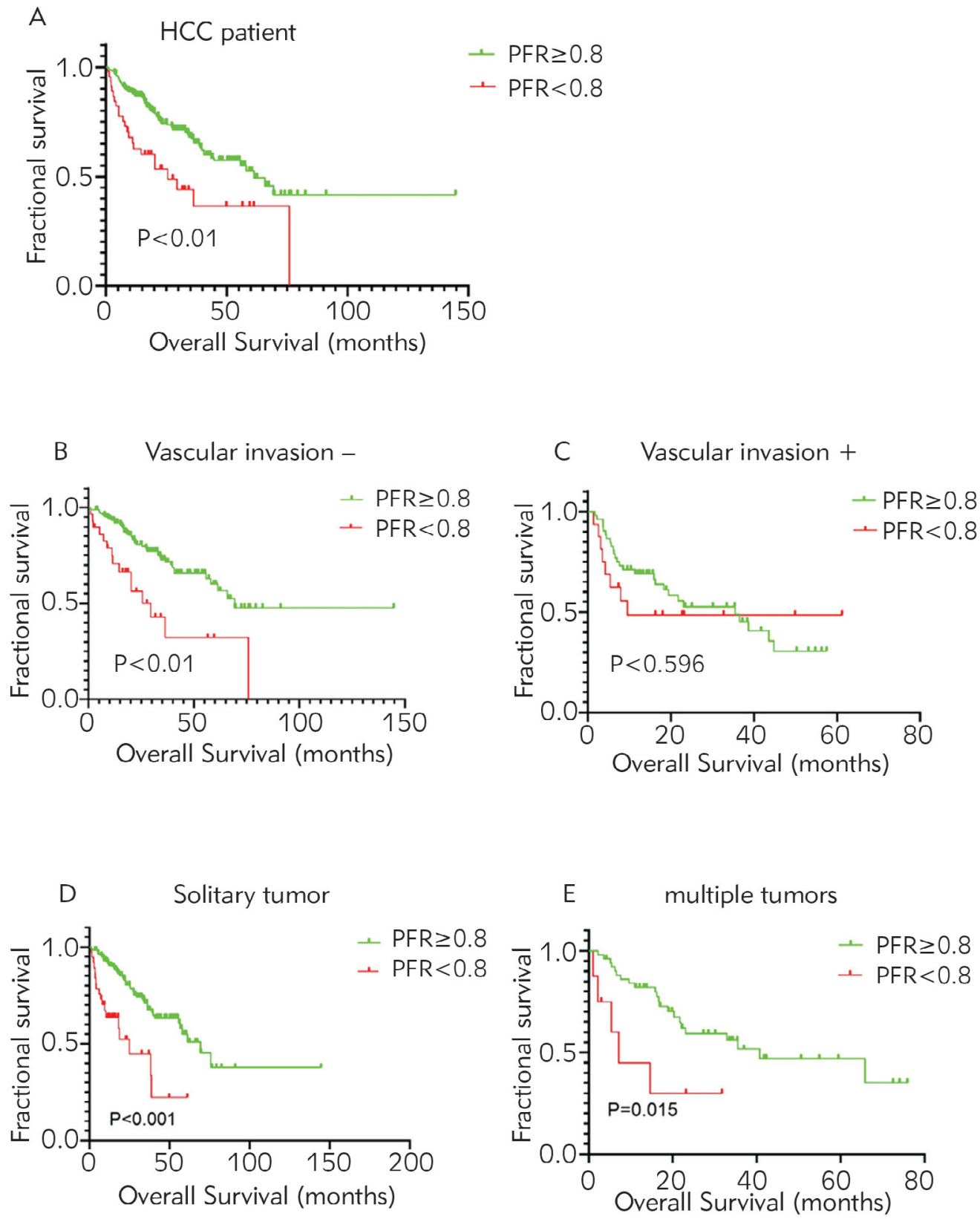

Figure 2 Kaplan-Meier curves for OS according to the PFR in each subgroup and the total HCC patients. A. total HCC patients, B. vascular invasion-negative subgroup, C. vascular invasion-positive subgroup, D. solitary tumour subgroup, and E. multiple tumours subgroup.

$P=0.000)$, and tumour size $(\mathrm{HR}=2.188 ; 95 \% \mathrm{Cl}$, $1.240-3.859 ; P=0.007$ ) were verified to be independent prognostic factors in patients with HCC (Table II).

\section{Survival PFR analysis}

This study used Kaplan-Meier analysis to determine the prognostic value of the PFR. Low PFR levels
$(<0.8)$ were associated with short OS (Figure 2A). Based on vascular invasion and the number of tumours, a separate subgroup analysis was also conducted to investigate the significance of the PFR for the prognosis of HCC patients. Moreover, short OS was found in patients with low PFR in the solitary and multiple tumour subgroups $(P<0.001$ and $p<0.001$, respectively) and the vascular invasion-negative subgroup $(P<0.001)$ but not in the vascular invasionpositive subgroup ( $p=0.596$; Figure $2 B, 2 C, 2 D, 2 E$ ). 


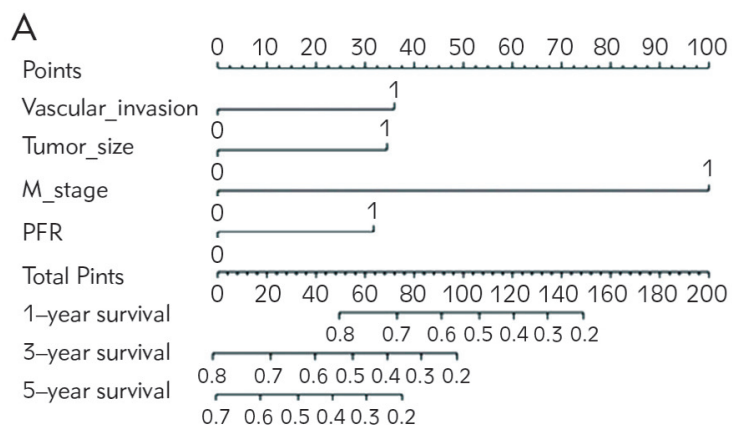

C

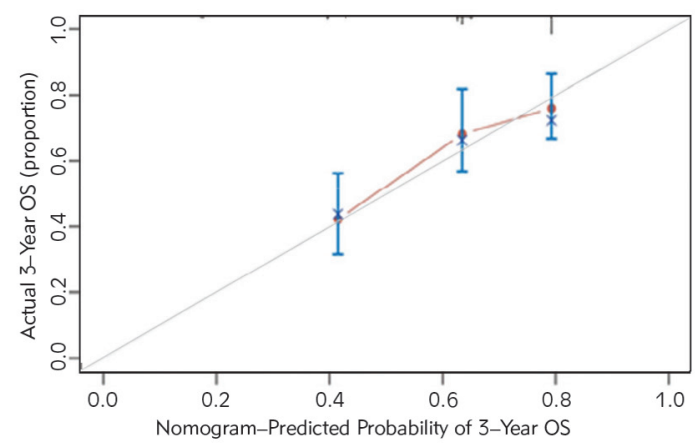

$n=269 d=96 p=4,89$ subjects per group $X-$ resampling optimism added, $B=1000$ Gray: ideal

\section{B}

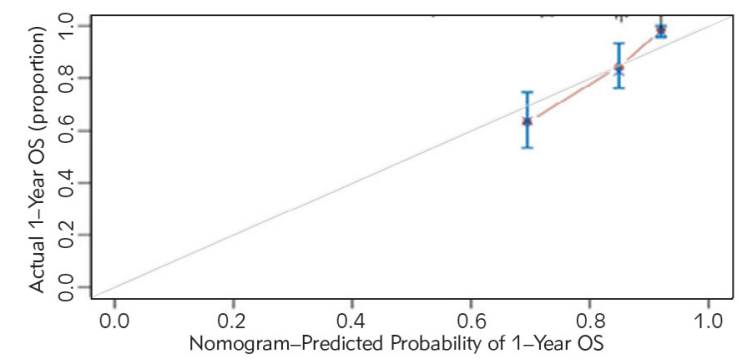

$n=269 d=96 p=4,89$ subjects per group $\quad X$ - resampling optimism added, $B=1000$ Gray: ideal Based on observed-predicted

D

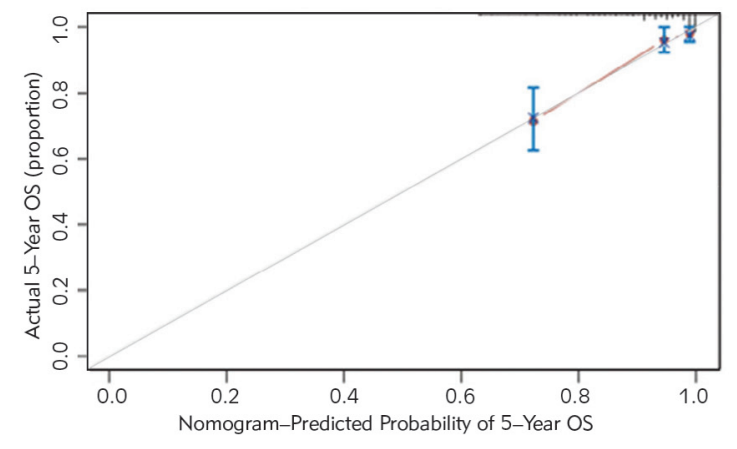

$n=312 d=33 p=5,104$ subjects per group $X$ - resampling optimism added, $B=1000$ Gray: ideal

Figure 3 The PFR was an independent predictive factor for disease progression in HCC patients. A. Nomogram predicting the OS of HCC patients. B. 1-year OS calibration plot. C. 3-year OS calibration plot. D.5-year OS calibration plot.

A

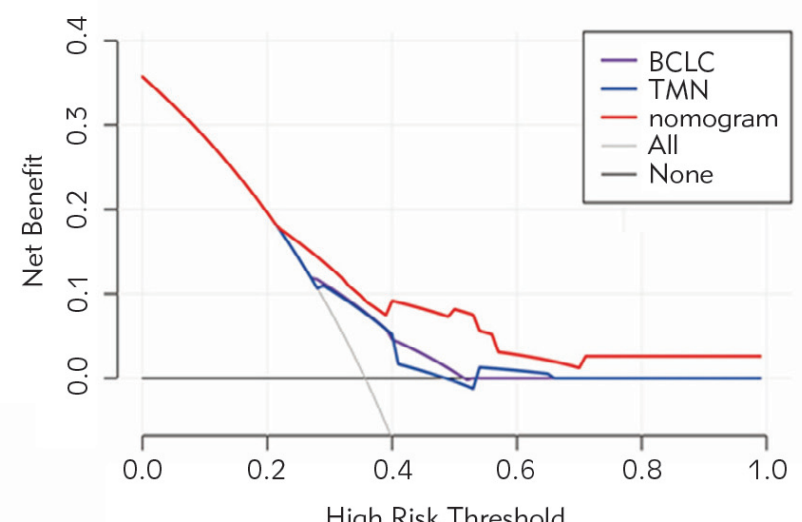

B

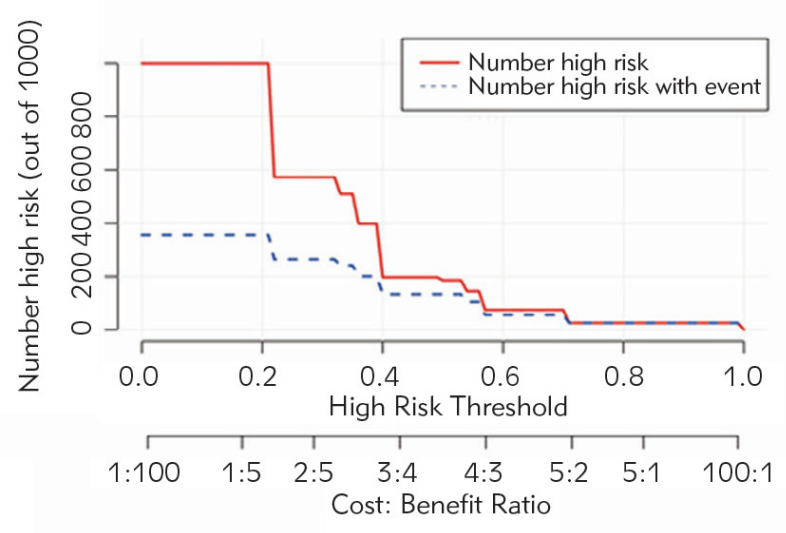

Figure 4 Decision curve for the disease progression of HCC patients. A. Nomogram, red line; BCLC stage, blue line. TMN stage, purple line. The abscissa of this graph is the threshold probability, and the ordinates are the net benefit. B. Clinical Impact Curve. 
Development and validation of nomograms for predicting OS in HCC patients

The nomograms can be explained by adding up the number of points assigned to each variable at the top of the scale. At the bottom of the scale, the total score translates into predicting the patient's 5-year probability of mortality. A nomogram, based on independent risk factors (the PFR, vascular invasion, $M$ stage, tumour size), was established to predict $O S$ in HCC patients (Figure 3A). The C-index for the OS nomogram was $0.715(95 \% \mathrm{Cl}, 0.662-0.768)$. Moreover, the calibration curves by internal validation demonstrated good agreement between the predicted and actual probability of 1-, 3- and 5-year OS (Figure $3 B, 3 C, 3 D)$. The decision curve analysis found that the nomogram model that included the PFR had better net benefits than the model that included the BCLC and TNM stages to identify OS for HCC patients (Figure 4).

\section{Discussion}

Malnutrition and fibrinogen abnormalities are common in cancer patients and have major effects on their quality of life, treatment outcomes, and prognosis $(11,12)$. This study indicates that a low preoperative PFR $(<0.8)$ is an independent risk factor for OS in HCC patients.

Chronic infections, including $\mathrm{HCC}$, cause $>15 \%$ of malignancies worldwide (13). Studies have shown that systemic inflammatory responses boost angiogenesis and tumour invasion by upregulating cytokines (14-16). This shows that the inflammatory response plays a critical role in tumorigenesis and tumour development. Furthermore, the two functions of prealbumin may be related to the occurrence and prognosis of tumours. The first is that inflammation is associated with decreased prealbumin levels in several studies $(17,18)$. Moreover, prealbumin levels may be affected in other ways during inflammation because cytokines (e.g., IL-6, IL-1, and TNF- $\alpha$ ) can downregulate synthesis (19) and increase vascular permeability (20). The second is that prealbumin can respond to the nutritional status of the reaction body. Serum prealbumin has a shorter half-life than albumin and is synthesised by hepatocytes. However, synthesis rapidly declines when hepatocytes are damaged. Furthermore, tumours cause protein malabsorption in the body and can also cause prealbumin levels to decline. Studies have recently shown that hypoproteinaemia is a poor prognostic indicator of oesophageal and colorectal cancers $(21,22)$.

Fibrinogen is the most acutely reactive plasma protein (1). It plays an important role in activating the coagulation cascade (23). Moreover, fibrinogen is also the key factor in regulating the inflammatory cascade through the interaction of ligand-receptor mechanisms involving immune cells (e.g., monocytes and microvasculature) $(2,24,25)$. Some studies have indicated that fibrinogen can be endogenously syn- thesised by cancer cells $(26,27)$. Meanwhile, highly concentrated fibrinogen induces epithelial-mesenchymal transition, which increases cancer cell invasion and metastasis using a cell line model by increasing vimentin expression and decreasing E-cadherin expression (28).

Therefore, in theory, prealbumin and fibrinogen are two valuable markers for monitoring HCC progression. Furthermore, this study showed that the PFR, an inflammatory marker, is a potential prognostic factor for HCC patients, combining the two factors of HCC patients' nutritional status and inflammatory response status and having the advantages of low cost and convenience, rapidity, and easy detection.

This study tried to explain the prognostic value of the PFR for HCC patients. X-tile was used to calculate the optimal PFR cut-off value of 0.8. Moreover, many studies previously used the receiver operating characteristic (ROC) curve to select the cut-off value. However, most of the ROC curves included only the event outcomes and experimental indicators but did not include important factors for cancer prognosis. The X-tile software precisely includes the time worth choosing as the cut-off value. Thus, the cut-off value of this article may be more accurate. Furthermore, this study suggests that the PFR is associated with OS and DFS in HCC patients in univariate analysis, and the PFR is related to the patient's OS $(\mathrm{HR}=2.123 ; 95 \% \mathrm{Cl}$, 1.271-3.547; $P=0.004)$ and has nothing to do with DFS in multivariate analysis. The risk of mortality of HCC patients with a low PFR is significantly increased. Moreover, the nomogram was used to establish the prognostic model of liver cancer, and the accuracy of the nomogram was proven by calibration, decision, and clinical influence curves. The nomogram shows that the PFR has an important predictive value.

Although the PFR can predict OS in HCC patients, there are some limitations in this study. First, this singlecentre retrospective study may have selection bias as it only included HCC patients undergoing surgical resection. Moreover, this study does not represent HCC patients who refuse surgery for different reasons. Second, verification queues are lacking to verify whether the findings of this study are commonly used. Therefore, the results of this study need to be further verified in forward-looking and large-scale cooperative research.

\section{Conclusion}

In conclusion, the results of this study suggest that the PFR $(<0.8)$ is a prognostic indicator of OS in HCC patients. Thus, a PFR-containing nomogram can be used as a more practical model for evaluating $\mathrm{OS}$ in HCC patients.

\section{Conflict of interest statement}

All the authors declare that they have no conflict of interest in this work. 


\section{References}

1. Lee JW, Kim MW, Choi NK, et al. Double primary hepatic cancer (sarcomatoid carcinoma and hepatocellular carcinoma): A case report. Mol Clin Oncol 2014 Nov; 2(6): 949-52.

2. Jemal A, Bray F, Center MM, et al. Global cancer statistics. CA: a Cancer Journal for Clinicians 2011; 61(2): 69-90.

3. Shu Y-J, Weng H, Bao R-F, et al. Clinical and prognostic significance of preoperative plasma hyperfibrinogenemia in gallbladder cancer patients following surgical resection: a retrospective and in vitro study. BMC Cancer 2014; 14(1): 566.

4. Morano MT, Mesquita R, Da Silva GP, et al. Comparison of the effects of pulmonary rehabilitation with chest physical therapy on the levels of fibrinogen and albumin in patients with lung cancer awaiting lung resection: a randomized clinical trial. BMC Pulm Med 2014 July 28; 14: 121.

5. Hefler-Frischmuth K, Lafleur J, Hefler L, et al. Plasma fibrinogen levels in patients with benign and malignant ovarian tumors. Gynecol Oncol 2015 Mar; 136(3): 56770.

6. Matsumoto M, Matsuura T, Aoki K, et al. An efficient system for secretory production of fibrinogen using a hepatocellular carcinoma cell line. Hepatology Research 2015; 45(3): 315-25.

7. Fu S, Niu Y, Zhang $X$, et al. Squamous cell carcinoma antigen, platelet distribution width, and prealbumin collectively as a marker of squamous cell cervical carcinoma. Cancer Biomarkers 2018; 21(2): 317-21.

8. Cai W, Kong W, Dong B, et al. Pretreatment serum prealbumin as an independent prognostic indicator in patients with metastatic renal cell carcinoma using tyrosine kinase inhibitors as first-line target therapy. Clinical Genitourinary Cancer 2017; 15(3): e437-e446.

9. Kawai $\mathrm{H}$, Ota $\mathrm{H}$. Low perioperative serum prealbumin predicts early recurrence after curative pulmonary resection for non-small-cell lung cancer. World Journal of Surgery 2012; 36(12): 2853-7.

10. Yue W, Liu Y, Ding W, et al. The predictive value of the prealbumin to fibrinogen ratio in patients with acute pancreatitis. International Journal of Clinical Practice 2015; 69(10): 1121-8.

11. READ JA, CHOY SB, BEALE $P$, et al. An evaluation of the prevalence of malnutrition in cancer patients attending the outpatient oncology clinic. Asia Pacific Journal of Clinical Oncology 2006; 2(2): 80-6.

12. Zhang D, Zhou X, Bao W, et al. Plasma fibrinogen levels are correlated with postoperative distant metastasis and prognosis in esophageal squamous cell carcinoma. Oncotarget 2015 Nov 10; 6(35): 38410-20.

13. Ulich T, Del Castillo J, Keys $M$, et al. Kinetics and mechanisms of recombinant human interleukin 1 and tumor necrosis factor-alpha-induced changes in circulating numbers of neutrophils and lymphocytes. The Journal of Immunology 1987;1 39(10): 3406-15.

14. Coussens LM, Werb Z. Inflammation and cancer. Nature 2002; 420(6917): 860-7.

15. Balkwill F, Mantovani A. Inflammation and cancer: back to Virchow? The Lancet 2001; 357(9255): 539-45.

16. Jaiswal M, LaRusso NF, Burgart $\sqcup$, et al. Inflammatory cytokines induce DNA damage and inhibit DNA repair in cholangiocarcinoma cells by a nitric oxide-dependent mechanism. Cancer Research 2000; 60(1): 184-90.

17. Liu M, Yang J, Yu X, et al. The role of perioperative oral nutritional supplementation in elderly patients after hip surgery. Clinical Interventions in Aging 2015; 10: 849.

18. Rambod M, Kovesdy CP, Bross R, et al. Association of serum prealbumin and its changes over time with clinical outcomes and survival in patients receiving hemodialysis. The American Journal of Clinical Nutrition 2008; 88(6): 1485-94.

19. Beck FK, Rosenthal TC. Prealbumin: a marker for nutritional evaluation. American Family Physician 2002; 65(8): 1575.

20. Ingenbleek $Y$, Young VR. Significance of transthyretin in protein metabolism. Clinical Chemistry and Laboratory Medicine 2002; 40(12): 1281-91.

21. Pan $P, T a o$ G, Sun XC. Subjective global assessment and prealbumin levels of esophageal cancer patients undergoing concurrent chemoradiotherapy. Nutricion Hospitalaria 2015; 31(5): 2167-73.

22. Byström $P$, Berglund $\AA$, Nygren $P$, et al. Evaluation of predictive markers for patients with advanced colorectal cancer. Acta Oncologica 2012; 51(7): 849-59.

23. Tennent GA, Brennan SO, Stangou AJ, et al. Human plasma fibrinogen is synthesized in the liver. Blood 2007; 109(5): 1971-4.

24. Adams RA, Passino M, Sachs BD, et al. Fibrin mechanisms and functions in nervous system pathology. Molecular Interventions 2004; 4(3): 163.

25. Solovjov DA, Pluskota E, Plow EF. Distinct roles for the a and subunits in the functions of integrin $a M 2$. Journal of Biological Chemistry 2005; 280(2):1336-45.

26. Simpson Haidaris P, Rybarczyk B. Tumors and fibrinogen: the role of fibrinogen as an extracellular matrix protein. Annals of the New York Academy of Sciences 2001; 936(1): 406-25.

27. Sahni A, Simpson Haidaris P, Sahni S, et al. Fibrinogen synthesized by cancer cells augments the proliferative effect of fibroblast growth factor 2 (FGF 2). Journal of Thrombosis and Haemostasis 2008; 6(1): 176-83.

28. Tian $Y$, Hong $M$, Jing $S$, et al. Clinical and Prognostic Effect of Plasma Fibrinogen in Renal Cell Carcinoma: A Meta-Analysis. Biomed Res Int 2017; 2017: 9591506. 